\title{
Folk Songs and How 'Amal Dunqul Uses Them in His Poetry
}

\author{
Eisam Asaqli ${ }^{1}$, Mariam Masalha $^{2}$ \\ ${ }^{1}$ The Arab Academic College for Education in Israel, Haifa, Israel \\ ${ }^{2}$ Tel Aviv University, Tel Aviv, Israel \\ Email: eisamasaqli@gmail.com,mariammasalha@gmail.com
}

How to cite this paper: Asaqli, E., \& Masalha, M. (2020). Folk Songs and How 'Amal Dunqul Uses Them in His Poetry. Advances in Literary Study, 8, 78-105. https://doi.org/10.4236/als.2020.82008

Received: January 27, 2020

Accepted: April 23, 2020

Published: April 26, 2020

Copyright $\odot 2020$ by author(s) and Scientific Research Publishing Inc. This work is licensed under the Creative Commons Attribution International License (CC BY 4.0).

http://creativecommons.org/licenses/by/4.0/

\begin{abstract}
This study deals with the use of folk songs in two poems by the Egyptian poet 'Amal Dunqul (1940-1983), 'iJāza 'là Shätì' al-Bahr (A Seaside Vacation) and the Al-hidād Yalīqu bi Qatr Al-nadā (A Mourning Becomes Qațr Al-nadā), The study reveals the cultural heritage and references from which 'Amal Dunqul draws in his poetry. It further examines the reasons and motives that prompted the poet to employ these sources. The study shows that 'Amal Dunqul, who came from the village, reveals his unfamiliarity with city life and the various psychological, social and political shocks it inflicts on him. He sees that the poet's life in the city is full of anxieties and is very black; he sees that he is suffering living there. Dunqul compares his status to that of others. He feels attuned to the spirit of the nation, and he believes that he belongs to it. He uses Egyptian folk songs and reflects on their content to criticize the prevailing political, social and economic conditions. Since he dreams of a more beautiful future, he believes that poetry should be a voice of opposition and resistance to the state of reality. Poetry, for him, expresses the rejection of the humiliation heaped upon us. Dunqul leverages his cultural heritage to increase peoples' national identity. He quotes Egyptian folk songs and roundelays, including them in his poetry after changing their context to decry the country's political and moral corruption, and the loss of Egypt's firm and moral political leadership. His poems express his sadness and grief because of the political and moral corruption on the one hand, and the infirmity of presidents on the other.
\end{abstract}

\section{Keywords}

'Amal Dunqul, Folk Songs, Political and Moral Corruption, Nationalism, Resistance

\section{Introduction}

Historically, Arabic folk literature, unlike other forms of Arabic literature, has 
not received attention as a separate literary genre, a form of individual literary creativity, with its own unique artistic features, advantages and values. This situation is attributed to its spread among the general public and its reliance on spoken language. A look at the history of folk literature reveals that it went through several stages until proving its moral value and being recognized by scholars and critics as a legitimate area for serious study. Over the years, this genre has oscillated between canonical and non-canonical literature. Folk literature has two types of critics. The first considers it a vulgar folk narrative unworthy of attention and study, and the other sees it as an elegant literature that belongs to the canonical literature that examines peoples' issues, concerns and hopes, and thus deserves attention, evaluation and criticism.

After World War II, the interest in folk literature increased. Some critics considered it a mirror of reality. It was seen as the voice of the people and the public, which led scholars to examine it seriously and resulted in critical inquiry into it in terms of content and style. They believed that it is a useful tool of popular expression with special esthetic features and intellectual orientations. It was adopted as an important source and independent literary type with its resources and supporters; thus, it moved from the margin to the center.

Today, poets and writers also explore folk literature, looking at its types, treasures and energy. They employ and link these to their contemporary experiences. They see that the formation of the intellectual, emotional and psychological Arab character cannot be expressed without through returning to, understanding and absorbing its cultural heritage. Among these poets is the Egyptian poet 'Amal Dunqul (1940-1983).

This research studies the employment of folk songs in the poetry of 'Amal Dunqul through two poems: 'iJāza 'lā Shăti' al-Bahr (A Seaside Vacation) and Al-ḥidād Yalīqu bi Qaṭ Al-nadā (Mourning Becomes Qaṭr Al-nadā). The research seeks to achieve the following objectives:

- Reveal the reasons Dunqul employed folk songs and the extent of their connection to the poet's vision and contemporary experiences.

- Uncover the relationship between the poet's past and present as revealed by the two poems.

- Show the poet's attitude toward his cultural heritage and the political and social reality in which he lives.

- Demonstrate the methods employed by the poet to surmount the outdated elements of his cultural heritage and replace them with new ones for the purpose of portraying the modern Arab reality.

- Bridge the gap in academic studies on this issue.

- Show the importance of folk songs in giving the reader a picture of the political and social conditions in which the poet lived.

- Raise the awareness of their history and cultural and national heritage to foster the growth of the Arab people intellectually and psychologically.

The article is organized as follows. In Section 2, we discuss the origins of the 
genre known variously as folk literature. In Section 3, we detail the characteristics of folk literature, explaining what makes this a separate and unique genre. In Section 4 , we move from the general to the specific-the folk song, defining it and then describing its features. In Section 5, we examine 'Amal Dunqul's two poems in light of our preceding discussion of folk literature, and show he used them to span the centuries from the birth of Arab folk myths to the twentieth century unhappy state of Egyptian peoplehood. In Section 6, we summarize and conclude the article.

\section{Folk Literature}

\subsection{Introduction}

The term "folklore" was first coined by William Thoms in 1846. He referred to folklore in his letter to the Athenaeum to replace "popular antiquities" and "popular literature". Initially, the word had been used in hyphenated form "folk-lore," but later on the hyphen was discarded. William Thoms meant to include manners, customs, observations, superstitions, ballads, proverbs and so on, in the term "folklore," which he summarized as the lore of the people. Today, critics and scholars Define "folklore" as the sum total of human creativity. It encompasses the customs, games, beliefs, festivals, and practices which human societies have owned through tradition from generation to generation. It includes literature, performing and non-performing arts, paintings, sculptures, arts and crafts, embroidered quilts, alpanas and their related mechanisms and designs, which have been handed down by tradition to the societies from previous generations through word of mouth or traditionally by non-oral means (Kutty, 2002: p. 7, 9).

Folk literature, also called folklore or oral tradition, is the lore (traditional knowledge and beliefs) of cultures having no written language. It is transmitted by word of mouth and consists, as does written literature, of both prose and verse narratives, poems and songs, myths, dramas, rituals, proverbs, riddles, and the like. Nearly all known peoples, now or in the past, have produced it. Regarding the origins of folk literature, as too the origins of human language, there is no way of knowing. No literature available today is primitive in any sense, and only the present-day results of practices extending over many thousands of years can be observed. Speculations, therefore, can only focus on such human needs that may engender oral literature, not on its ultimate origin.

Nor can any evolution in folk literature or overall development be alluded to explicitly. Each group of people, no matter how small or large, has handled its folk literature in its own way. Depending as it does upon the transmission from person to person and being subject to the skill or the lack thereof of those who pass it on and to the many influences, physical or social, which consciously or unconsciously affect a tradition, what may be observed is a history of continual change. An item of folk literature sometimes shows relative stability and sometimes undergoes drastic transformations (Thompson, 2017). 
Folk literature is part of the large multisystem of folklore. Folk literature is a manifestation of a national heritage. It is a written compilation of thousands of years of folklore, reflecting aspects of a people's life, customs and experiences, and employs a simple folk language. Folk literature includes folk music, folk dance, folk songs, proverbs, tales, legends and more.

\subsection{Definition of Folk Literature}

Folk literature includes the basic features of folklore, performs functions beneficial for the public that circulates it and is categorized as a verbal art. It is distinguished from other folklore elements by its adoption of literary artistic language to serve and entertain its audience and help them perform their rituals (Khūrī, 2013: p. 35).

Folk literature is an unwritten and oral literature belonging to a nation or community. It is a literature that originates from a people and it is circulated among its different classes. It is unlike elegant literature, which may sometimes be limited to intellectuals and salon writers. Among its most important elements are folk stories, folk songs, folk proverbs, chants, legends, puzzles, folk puzzles, maxims as well as prayers, wishes and expressions used by the community from within which it arose in different situations. To understand folk literature, all these parts of the whole must be taken into consideration by historians ('Abdullāh, 2018: p. 28). According to Stith Thompson, folk literature, also called folklore or oral tradition, the lore (traditional knowledge and beliefs) of cultures having no written language. It is transmitted by word of mouth and consists, as does written literature, of both prose and verse narratives, poems and songs, myths, dramas, rituals, proverbs, riddles, and the like. Nearly all known peoples, now or in the past, have produced it (Thompson, 2017).

Researchers and thinkers in the Arab world have not been able to agree on a precise definition of folk literature. Mahūmd Dhihnī believes that folk literature arises as a work of either a formal or informal literature type. Afterwards, the characteristics it develops qualify it as folk literature. Jalāl Al-ḥanafĩ says,

It is a right that cannot be denied, the public have their own interpretation in thinking and expressing. Their literature was often characterized as simple and naïve; it might have some concentration, depth and enjoyment, because the general passion is simple and uncomplicated, which can absorb many things and events, and can express different cases of anger, praise, and criticism away from any confusion and ambiguity (Mursī, 1987: p. 16).

According to the Italian Orientalist Giovanni Konva, folk literature is a literature common in the social categories called public literature. It uses the local, semi-standard dialect, which is easy, and incorporates the current colloquial language (Khadrāwī, 2015: p. 76). 'Aḥmad Rushdī believes that "folk literature is a traditional literature, or the literature of the peasants. The tool of this traditional folk literature is the colloquial dialect" (Mursī, 1987: p. 21).

Muhammdd Marzūkī and Father Yūsuf Qūshāgjī consider folk literature syn- 
onymous with the term folklore. Qūshāgji refers to the role of the UNESCO Foundation in urging nations to spread their folklore because of its usefulness in identifying the history, beliefs, myths and customs of people. On the other hand, Marzūki believes that Arab thinkers replaced with their word for "folklore" with the European words folk literature. 'Abd al-ḥalām Yūnis believes that "folk literature for many scholars and scientists is synonymous with folklore" (Mursī, 1987: p. 22).

'Āṭif 'Ațiyya defined folk literature as

[T]he sum of what the group said; it is anything that was transmitted through speech from one generation to another in the colloquial language. The evidence for its importance is reflected in its transmission and in preserving its circulation and continuance in memories since it represents the cultural heritage that expresses the group's values and ideals in life ('Ațiyya, 2016: p. 103).

Mahmūd Taymūr is careful in his use of the adjective "folk" since it describes entities that are low and cheap or "substandard", as he understands it. He interprets this idea as follows:

[T] he adjective "folk" was often used for the cheap and for those below the level. We describe an idea as "folk", which means that is used in line with desires without using wisdom. We also describe a joke as "folk", meaning that it does not lack whims and regrets, and we use this adjective to describe a type of cloth that is made with a non-luxurious fabric. Anything that is attributed to the people is considered far from elegance, originality, and quality.

Taymūr further explains his opinion, saying: "the vulgar literature cannot be called folk, because the vulgarity and degradation are associated with the writers of literature, not with the people. In any case, folk literature cannot mean the literature of decay, vulgarity and decadence" (Taymūr, 1960: pp. 168-169).

\section{Features of Folk Literature}

Folk literature has nine major characteristics.

\subsection{Popularity}

The primary characteristic of folk literature is its popularity, in the sense that it belongs to the people and not to the individual (Ibrāhim, 1981: p. 84). This group of people includes both the audience of formal and colloquial literature. This makes folk literature a literature belonging to all the assorted and varied kinds of individuals comprising the group of people. It comes from the heart of the people, which refers to their psychology, orientation and beliefs, in a way that the illiterate and the educated understand. It emerges from the feelings and needs of the people and develops in accordance with such needs (Khūrī, 2013: p. 35). It is dispersed through "the heritage of exchange", one of the most im- 
portant characteristics of folk literature, at the folk level and is taken up by the people and disseminated because the literature is popular (Dhihnī, 1972: p. 83).

There are some social scientists who hold the view that folklore is the creation of a group of people who belong to the same contiguity of dwelling place and culture regardless of whether the location of residence is city, town or village. These scholars are of the view that folklore is the creative product of a community sharing similar habitat and culture. Their customs and beliefs, the language spoken and the traditional patterns of livelihood share certain common characteristics. Their folklore is reflected in their creative ideas and is the common property of the community. Folklore, thus, is the product of human creativity, creation of people who live in a particular geographical area, sharing the same language, culture, mechanism of livelihood and living conditions. The life styles and traditions of the folk are characterized by a common identity. Folklore is the product of the creative ideas of the people who express such creativity through verbal, artistic or material forms, and this in turn is transmitted orally or in written form or through some other medium from one generation to another, belonging to a literate or nonliterate society, tribal or non-tribal, rural or urban people (Kutty, 2002: p. 8).

In sum, folk literature carries the heritage of the entire nation. It does not express the idea of the individual, but the idea of the community; thus, it becomes its living and moving conscience, which expresses the group's life experiences, heritage, pains and hopes. Hence its artistic characteristics originate in its vocabulary and composition (Bidīr, 1986: p. 17). Folk literature is characterized by the collective spirit; the community is the one that shapes the text according to its mood and circumstances. Further, the folk author expresses the conscience and feelings of the community before expressing his own (Bin al-shaykh, 2007). Fārūk Khurshīd believes that the true author of folk text is its recipient (Khurshīd, 1994: p. 23).

\subsection{Author's Anonymity}

The subjectivism of this literature is eliminated or immersed in the group generating it as an objective expression of the group-self through general collective tendencies. Therefore, this literature does not belong to the individual, is not his property. It becomes the property of the public. It starts subjectively at the beginning, then percolates through the group until it is transformed and breaks free to become part of the group's heritage. The group adds its energy, knowledge, fiction and feelings to such literature. In this way, the text appears different from the original text; this process conceals the identity of the original author (Khūrī, 2013: p. 37). According to 'Ibrāhīm 'Abd al-ḥāfiz, the first feature that researchers examine in folk literature is a piece's composition. Is it written by an individual or the group? Do all the people get together to write the piece of folk literature under study or was it composed by a particular individual? $\mathrm{He}$ adds, "the participation of all the types of individuals that comprise the nation in 
writing folk literature may be achieved in one way or another. For instance, in each folk tale, there is a listener and a storyteller and the listener belongs to a large audience of people" ('Abdu al-hāfiż, 2013: p. 21).

\subsection{Legacy}

In its transition from one generation to another, folk literature depends on narration and memorization, and as its artistic form and content move through society and time, it adapts itself to social, political and economic changes. It modifies the basics of its different arts, which are confined to three fields-folk proverbs, folk songs, and folk biographies (Bidīr, 1986: p. 19). It has been shown that folk literature can float on the temporal surface to meet each era with the same novelty and vitality. It also meets each generation with the same emotion and excitement (Dhihnī, 1972: p. 83).

\subsection{Benefits}

Folk literature is used in the various popular folk texts. It performs tasks useful for the life of the community. The patient remembers it during his illness, the poor man in his poverty, and the happy man when he is joyful. It further represents the peoples' refuge whatever their circumstances since it speaks of their conditions with a beauty that cannot be provided by daily speech. Folk literature lives among people as a necessity, providing balance and facilitating continuity of their lives (Al-qalamāwī, 1966: p. 89).

\subsection{Oral and Changing}

While going through the definitions one can attribute the reasons for the dispute mainly to the oral tradition of folklore. In a society where the masses are illiterate, the oral tradition is the means through which propagation of the necessary elements of culture takes place. In such a society, scholars used the term "folklore" to refer to the language of the people, the system of their livelihood like hunting, agriculture, customs relating to marriages, deaths, etc., and the basic code of conduct, all of which are transmitted orally. According to scholars, all elements of learning that are passed through an oral tradition from generation to generation in a society belong to the domain of folklore. However, it may not be wise to consider all that is passed on orally as folklore. It is, perhaps, more reasonable to limit folklore to the creative aspects of a society, as reflected in its day-to-day life and expressed in material or non-material forms, rather than referring purely to the form of transmission, whether written or oral (Kutty, 2002: p. 7).

Stith Thompson believes that the most obvious characteristic of folk literature is its orality. In spite of certain borderline cases, it normally stands in direct contrast to written literature. The latter exists in manuscripts and books and may be preserved exactly as the author or authors left it, even though this may have happened centuries or even millennia ago. Through these manuscripts and books the thoughts and emotions and observations and even the fine nuances of style 
can be experienced without regard to time or distance. With oral literature this is not possible. It is concerned only with speaking and singing and with listening, thus depending upon the existence of a living culture to carry on a tradition. If any item of folk literature ceases to exist within human memory it is completely lost (Thompson, 2017).

Folk literature is based on utterance (being oral) in its circulation, which is considered one of its most prominent qualities and enables it to spread. In this, it is similar to colloquial literature (Dhihnī, 1972). Francis Utley believes that folk literature is "a verbally transmitted literature" and William Bascom defines it as "a literature that is verbally/orally transmitted". Dan Ben Amos believes that the oral transmission element is the final step used by folklore experts when defending the characteristics that distinguish their material (Bauman, 1992). From the first moment when they receive the individual product, people start transmitting and preserving it in their memories and add more of a popular element. Folk literature transmission throughout the ages has been done by relying on men's or women's memories and through the spoken word more than the written word. This type of transmission method affects the flexibility of the literary genres such as stories and puzzles, allowing deletion, addition and amendment. The oral frequency also plays an important role in the flexibility of the folk genres, with those transmitting the folk literature through the generations participating in the amendment process from the start (Al-jawharī, 2002: p. 19).

\subsection{Originality}

According to the researcher Sa īd Muhammad, originality is a distinctive feature of folk literature given that is has been associated with man and his development, which was expressed through dancing and singing, a quintessential part of people's social life throughout the ages. Sir James Frazer stated: "Folk literature, in its originality, resembles the magic of the past. Magic was made using a mythical literary language; however, its rituals were separate from legends" (Muhammad, 1998: p. 18). Originality means granting folk literature the right to appear on behalf of elegant literature, such as occurred when Egyptian folk literature emerged and spread in the 8th century BCE (Șāliḥ, 1971: p. 17).

\subsection{Realism}

Folk literature, through form and content, is linked to the issues of nation and reality. The imaginary trends in the worlds of strangeness and meta-nature are but a folk reading of this reality, which is sometimes contradictory and, at other times, harmonious. Folk literature is the mirror that reflects the true image of a community's life (Muhammad, 1998: p.19).

\subsection{Locality}

Folklore is the product of human creativity, creation of people who live in a particular geographical area, sharing the same language, culture, mechanism of live- 
lihood and living conditions. The life styles and traditions of the folk are characterized by a common identity. Folklore is the product of the creative ideas of the people who express such creativity through verbal, artistic or material forms, and this in turn is transmitted orally or in written form or through some other medium from one generation to another, belonging to a literate or nonliterate society, tribal or non-tribal, rural or urban people (Kutty, 2002: p. 8).

Folk literature is considered a regional literature, i.e., each region has its own distinctive folk literature, which is transmitted in the region's dialect. It might resemble the literature of the neighboring regions, but it continues to reflect characteristics, tendencies and inclinations of the people in that specific region (Khūrī, 2013: p. 41).

\subsection{Simplified Language}

Some researchers believe that colloquial language is one component of folk literature. Mahmūd Dhihnī differentiates between language and dialect, and the language of writing and the language of everyday conversation. He identifies the characteristics of colloquial literature and the way they differ from canonical and folk literature. He believes that folk literature "arises as either canonical or colloquial, and then is converted into a folk literature by the subjective characteristics. The language of such literature is not colloquial, but an easy and accessible standard language" (Dhihnī, 1972: p. 72). Jeries Khūrī, explaining his opinion on the language of folk literature, says, "The language cannot be a clear separator for what is folk or what is colloquial. It enables the fluent text to be transformed into a folk text" (Khūrī, 2013: p. 37).

\section{The Folk Song}

\subsection{Introduction}

The folk song is a lyric that is circulated by community members among themselves during their social events. Folk songs are part of folk literature; they are songs that are linked to the life of people, and to the customs, traditions and experiences of a nation, such as the songs of holidays, Christmas, marriage, hunting, harvest, and joyful nights, etc. Folk songs are transmitted verbally from generation to generation. They also express the feelings and wishes of the people and are a means of communicating joy.

\subsection{Definition of the Folk Song}

The Century Dictionary defines the folk song as "a song of the people; a song based on a legendary or historical event, or on some incident of common life, the words and generally the music of which have originated among the common people and are extensively used by them. The Dictionary of the English Language defines it as "a song belonging to the folk music of a people or area, often existing in several versions or with regional variations" (Wordnik, 2019). Macmillan Dictionary defines it as "a traditional song from a particular region or 
community, especially one that was developed by people who were not professional musicians" (Macmillan Dictionary, 2019).

Fawzì Al-'antìl defines the folk song as "an anonymous, lyrical song, which has originated among the public in the past and lasted for long time" (Al- antīl, 1978: p. 245). Others find that it is important to distinguish between folk songs and popular songs. Frank Kid Son defines the folk song as "a song that emerged among the people who used it after it settled among them until it was documented by the experts before the professional singers adopted it" (Shams al-din, 2008: p. 16, 31). Alexander Haggerty Krappe defines it as "an anonymous lyrical song that used to remain among people in the past and it still exists until now" (Națūr, 2008: pp. 14-15; author's translation from the original Arabic). Lev Polykavsky says that the folk song is composed by people to express their pain and suffering. He rejects the idea that these songs spread widely enough among people so that they can be called folk songs. He says, "the folk song is created by the people; it is not a song that lives in a folk atmosphere" (Națūr, 2008: pp. 14-15). Richard Weiss contradicts Polykavsky and asserts that "the folk song is not necessarily the song that people created but is the song that people sing and the one that performs functions needed by people" (Mursī, 1970: pp 10-11).

'Ahmed Mursī defines the folk song as:

...the repeated song that absorbs a collective portfolio whose literature is transmitted. It is based on the folk conscience, and it is varied with its varied occasions; its shape changes according to the framework in which it exists. The religious song is different from the job song and the two are different from the song of the children (Mursī, 1970: pp. 23-24).

Sa i id Muhammad defines the folk song in the following way:

[T] he folk song is issued by men and women on the same level and it is free from complexity, so it is easily memorized. It further has a musical tone. The folk song moves among people so it is attributed to the people; therefore, its creator is forgotten. It also reflects their feelings (Muhammad, 1998: p. 10). George Hertzog stated that "the folk song is the most famous song in society. It represents the poetry of the groups and their music whose manners are transmitted orally without the need for writing or printing" ('Ismā' îl, 2015).

The folk song is a form of public expression and represents an emotional escape for many of the psychological situations through which people go, because it allows them to express joy or sadness, as well as being a form of entertainment (Al-barghūthī, 1979: p. 14). The term "folk song" entered the Arabic language as a translation of the German term "volkid" and the English term "folk song" after the establishment of its concept among European scholars. Europe adopted the term following publication of Johann Gottfried Herder's book Stimmen der Völker in Liedern (2013), in which he collected German folk songs and characterized, for the first time, the feature of folk songs (Mursī, 1970: p. 8). 
Folk songs include the poetry and music of groups, which preserve the songs' heritage not by writing and printing but through the oral transmission (Herzog, 1950, 1032-1033). Accordingly, the folk song is linked to the life of the group in which it exists. Its forms, styles, functions and methods of performance vary until it becomes a powerful tool among the individual members of the group. It follows people at different stages of their lives and their circumstances. It is distinguished from the rest of the literary and folk genres by its melodies and music, and by relying primarily on words and structures (Khūrī, 2004: p. 67).

Folk songs, as a distinct genre, did not receive special attention from past Arab historians, especially music historians. They were concerned with classical singing, believing that folk songs were undeserving of their attention. They completely overlooked the mention of folk songs and some tackled it at length only when examining other lyrical genres. Only modern historians have examined the subject ('Ibrāhīm, 1981: p. 273).

\subsection{Characteristics of the Folk Song}

Folk song implies the use of music, and the musical tradition varies greatly from one area to another. In some places, the words of songs are of little importance and seem to be used primarily as support for the music. Frequently there are meaningless monosyllables and much repetition to accompany the voice or the musical instrument. In much of the world, drums and rattles, beating time by hands or feet, or the stroking of a harp give a strong rhythmic effect to folk singing. In other parts of the world, flutelike wind instruments or bowed fiddles of one kind or another affect the nature of folk song texts. In many places folk songs are of great importance, serving as excitement to war or love or as a part of religious or secular ritual. Through them, the group expresses its common emotions or lightens the burden of communal labor. In certain preliterate groups and sometimes elsewhere, folk songs are used for magic effects, to defeat enemies, to attract lovers, to invoke the favor of the supernatural powers. Sometimes the magic effect of these songs is so greatly valued that actual ownership of songs is maintained and their use carefully guarded. They may come to the owner in a dream or as the result of fasting or other austerities (Thompson, 2017).

Folk songs engage in men and women's everyday social life, and deal with and focus on large segments of people with different aspirations and orientations. Folk songs express the concerns and sorrows of human beings, their ambitions, hopes and joys. Hence, we understand that the folk song is the product of man's psychological need and moods. The folk song represents a safety valve for people in times of crisis. It is a means of fun and joy that helps them to do a difficult job and allows them to articulate their emotions and feelings (Mursī, 1970: p. 18). According to Muhammad 'Abdu al-laṭif, the folk song is as old as the existence of man; it constitutes spiritual food for him and it is sincere because it is in fact an honest picture of the feelings of people ('Abdu al-latiff, 1964: p. 97). The folk 
song speaks of many different social phenomena, and it is truer than poetry written in classical or standard Arabic since it is close to the community on one hand, and is linked directly to various personal, social and religious occasions, on the other (Bidir, 1986: p. 45).

It is difficult to delineate the general features of the folk song because of its wide dispersion and its strong association with memory and life. It has diverse forms and purposes (Khūrī, 2004: p. 67). The following characteristics are generally agreed upon by scholars as features of all folk songs.

1) Subjectivity

The folk song is characterized by its subjectivity since it comes from the spirit and conscience of people. Once composed, it is transmitted by people, and it is necessarily collective, although its text is considered individual, being subject to replacement, modification and addition (Krappe, 1967: p. 133). The folk song is edited by the people as they wish after they own it fully (Mursī, 1970, p. 10).

2) Lyrical

The folk song is linked to the melody to which it is sung, the instruments used to perform it and the manner in which the performer presents it. These characteristics require that its language be simple so people will interact with it without barriers. Its music is far from complex and it is attractive without any artificiality (Khūrī, 2013: p. 44).

3) Collective

The folk song is based on a collective performance. It expresses the feelings of the public and not only the feelings of its singers. The folk song is often the result of a collective effort and it is valid for different times and places, which validity makes it permanent ('Aḥmad, 2006: p. 106).

4) Rhythmical

The musical scale of traditional folk songs is an extension of the musical scale known by Arabs in the past.

5) Artistic

The folk song is considered the richest kind of folk genre in terms of its artistic quality and care taken in its presentation, to the degree that at times it becomes quite complex. Most of the rhetorical arts used in formal poetry are present in the folk song (Khūrī, 2004: pp. 68-69).

\section{5. 'Amal Dunqul's Use of the Folk Song in His Poetry}

We now move to examine how 'Amal Dunqul's poetry was influenced by folk songs and how his poems hark back to well-known folk songs. Our examination is based on his two poems: 'iJāza 'lā Shăti' al-Bahr (A Seaside Vacation) and Al-hidād Yalīqu bi-Qaṭ Al-nadā (Mourning becomes Qaṭr Al-nadā). The study seeks, on the one hand, to reveal the sources and features of the cultural heritage that Dunqul adopts and employs in his poems to portray the Arab reality and link it to his contemporary experiences and, on the other hand, works to uncover the reasons why the poet uses these cultural heritage sources. 
In recent decades, we are witness to a resurgence of interest by many researchers and critics in the Arab national heritage. By studying its elements, trends and branches, they aspire to revive it. The readings, concepts and uses of Arab cultural heritage vary, and poets, writers and artists have started to introduce it in different fields. They employ it in their work and link it to their contemporary experiences. Hence, their heritage has become an effective means for poets and writers through which to express their attitude to life, daily issues and concerns.

\section{'iJāza 'lā Shāți' al-Baḥr —A Seaside Vacation}

\section{1) The Poet and the City}

The poet's relation with the city is considered a prominent phenomenon in contemporary Arabic literature. Those who review the work (Dīwāns) of modern Arab poets often note that some of them have addressed this topic in one or more poems; they have either a positive or negative attitude towards it ( $\mathrm{Abu}$ Ghālī, 1995). 'Amal Dunqul, an Egyptian poet, addressed and argued with the city in several poems, including in Maqtal Al-Qamar (Killing of the Moon), Al-suways (Suez Canal), 'iJāza 'lā Shāṭi' al-Baḥr (A Seaside Vacation), and Hekāyat Al-Madina Al-Fiddiyya (Tale of the Silver City). In terms of the dialectic he uses when addressing the city in his poetry, 'Amal Dunqul does not abhor or resent the city in the romantic sense. The language he uses is an expression of his sense of his unfamiliarity with the new environment, for various psychological, social and political reasons (Ṭālibì, 2017: p. 81).

A keen and profound look at the poem reveals that the poet is describing his own psychological state and sufferings but also those of the people in Alexandria through the day. The poet's life is dark and he faces one problem after another. This darkness makes him sad, pains and shatters him. It surrounds him on all sides, filling his life with blackness, leaving no room for any hope. The poet also commingles his feelings with his nation's problems and intertwines his spirit with that of his nation. He feels that he belongs to the nation. Such problems and worries are dark and heavy, covering the sky and the horizon, and prevent light and hope from reaching both him and his nation. Perhaps, the poet's psychological state, weighed down with all his worries, makes him imagine such a sad and black case. In his words,

"August,

Alexandria,

And the iodine sparks in the lungs,

Whose passage is stopped by asthma and dust,

May's childhood is ageing,

And in the morning, we raise our white flags to the sea, surrendering,

So that the salt hits us, giving our skin freckles,

And we furnish the afternoon's carpet, and we sit above the sand,

We have fun in our mysterious, young sadness so that it would glow, 
When we tried to catch it, our hands were burned!

We desire the chaste breast,

How their freshness would dry up,

Producing a poison, with worms devouring a rotten apple”

(Dunqul, 1987: pp. 143-145; author's translation from the original Arabic).

In the above section, the poet describes the city using negatives. It lies in a prison with disease, darkness, death and despair, a prison that prevents freedom for everyone. All the landmarks of the earth have turned into wasteland; chaos is widespread among people. Falsehood, fraud and deception are the dominant laws; the strong eat the weak and the people live in endless mazes without hope of getting out of such a mess.

\section{2) Employing a Folk Song in a Poem}

There is no doubt that any nation no matter how modern it is, even while following the spirit of the times and technology, will always maintain the identity, authenticity and uniqueness that distinguishes it from other peoples. We find that such nations seek to revive their past glories and restore the memories of their heroes by disseminating the folklore of their national symbols, which reminds the people of their heritage and increases their attachment to its uniqueness and sacred rewards. A folk heritage expresses the people's view of various issues affecting their life and the events happening to them. Researchers studying a folk heritage realize its crucial role in the cultural life of nations, especially that it keeps pace with the nation as the latter moves through history. This feature has made folk literature a legitimate literature linked to reality and society, and may have led many creative writers, novelists and poets to engage with their particular folk heritage and benefit from its richness, stretching it far beyond its seeming limitations (Zakkūr, 2016). Valsala G. Kutty believes that every nation claiming to be a part of the civilized world is proud of its cultural heritage. Folklore is probably the most important and well-acclaimed component of the cultural heritage of a nation. It can reflect the essentials of a nation's cultural attributes as in a mirror and is recognized as a basis for its cultural and social identity. Nations all over the world are quite possessive about this valuable heritage and express very strong sentiments about the management of the rich resource (Kutty, 2002: p. 4).

Mounting sociopolitical changes, along with the incompetence of the postrevolutionary regimes in Egypt have functioned as adequate themes for the writings of 'Amal Dunqul. He adopted "speaking truth to power" as an ideology to not only document the consequences for such sociopolitical turbulence but also to face the incompetence of the authority. He employed this concept in his writings to empower his people to move to ask for their rights. He believed in the strong role of literature in changing societies. Dunqul was a real intellectual who courageously speaks truth to power fearless of any consequences (Elkholy, 2017).

Regarding employing one's cultural and national heritage, 'Amal Dunqul 
states, "inspiring heritage is not only a technical necessity, but also an education of the national conscience" (Al-gharfi, 2003: p. 45). A thorough and in-depth reading of 'iJāza 'lā Shặi'i' al-Bah̆r (A Seaside Vacation) reveals that 'Amal Dunqul uses the folk song to express the bitter Arab reality. Let us look at another passage from this poem where Dunqul employs the folk song:

"My friend who drowned in the ground is dead,

So, it embalmed him and kept his teeth,

Every day, when the morning comes out, I take one,

I throw it to the sun with the beautiful face

And I repeat: O sun, I will give you his pearl tooth.

That has no dust,

Except for the flavor of hunger,

Give it back, give it back, it tells us the right wisdom,

But it smiled with a pale smile.

And on the sea, there was a banner of sadness and anger of the wind,

And we, with the silence, carry his body above our shoulders,

Then we land on the city roads,

We stop passersby,

We ask them about the road to the cemetery and the lost journey,

But we in the end,

Went back to the seaside and the angry banner,

We started at the sea when we went to the cemetery,

How did we get back to him?

And how did the road become suspect?"

(Dunqul, 1987: pp. 145-143; author's translation from the original Arabic).

The inspiration Dunqul draws from his heritage takes two forms. The first is documentary-that is, he seeks to revive the heritage to praise and take pride in the past, and the second is using heritage as a tool for expressing contemporary reality (Masā'di, 2000: pp. 160-161). The difference between transmitting the heritage and employing it lies in how Dunqul deals with the heritage with a new spirit, and embraces his heritage using contemporary visions and ideas. The employment of his heritage is an advanced level in the writer's relation with it. It is a phase beyond the process of reviving and inspiring it; the poet is artistically dealing with his heritage. Here the writer examines the elements of the heritage from a contemporary perspective to recreate and reformulate them to fit into his new reality (Al-mikhlif, 2000: p. 46).

Dunqul borrows an Egyptian folk song frequently sung by people when a child loses his or her first tooth. Traditionally, the child will throw it into the sun as he sings:

"Sun, Sun

Take the buffalo's tooth

And grant me the bride's tooth" (Nazīr, 1967: p. 10).

This folk song, with its own local variation, is also part of the Libyan folk her- 
itage:

"O Sun, O Sun the apple eye of the cat,

Take the deer's tooth and give me the donkey's tooth".

In Arab folklore, donkey's teeth were a source of power (Bin 'Āmir, 2006: p. $41)$.

We also find that Kuwaiti children chant a similar song:

"O Sun, take the deer's tooth and give me the pearl's tooth" (Al-dūsarī, 2004: p. 107).

One can find similar songs in most Arab countries, with the main difference being the accent used to recite them. For example, in Tunisia, they say, "Sun, o sun, take the donkey's tooth and give me the deer's tooth". In Algeria and Morocco, they say, "O sun, take the donkey's tooth and give me the deer's tooth". In Iraq, they say, "Take the camel's tooth and give me the deer's tooth". In the Levant, they say, "Take the donkey's tooth and give me the deer's tooth", and finally, in Sudan, they say, "O sun's eye, take the donkey's tooth and give me the deer's tooth".

The song rests on the idea that the sun will compensate the person for the tooth that has fallen out by giving him a beautiful, new white tooth as in a bride's tooth. The sun here means the god Ra', a part of the ancient Egyptian heritage, who was symbolized by the sun. Dunqul, however, adopts this Egyptian folk myth while changing its content; he uses it to criticize social conditions (Kumîn, 1987: p. 162). Basma Al-Khafifi states that the terms "give me his pearl tooth" and "not having dust except the hunger flavor" are clear proof of Dunqul's irony and criticism of such situations. He exploits an ancient Egyptian custom to make it a metaphor for the deteriorating contemporary economic and social conditions (Al-khafifi, 2000: p.222).

Joseph 'Iskandar believes that the poem's semantics consist of the contextual relationships with the folk story of children who, when their teeth begin to fall out, throw the teeth into the face of the sun and make a wish for a new beautiful alternative to appear. Thus, the poem's message is framed nicely and becomes clear in the next part of the poem:

"And I repeat: O Sun, I give you his pearl tooth,

Without dust,

Except for the flavor of hunger,

Give it back, give it back, It tells us the right wisdom.”

(Dunqul, 1987: pp. 144-145; author's translation from the original Arabic).

This tooth, or nation, knows nothing except the flavor of hunger. The history of the nation is a history of hunger and dust. If we ask this tooth about its hunger or for how long it has been hungry, it will bring us new knowledge and teach us the hunger undergone by the nation ('Iskandar, 2005: pp. 175-176).

The twentieth century witnessed a growing interest in studying the role of intellectuals, and their ability to incur a significant change in their societies. In Representations of the Intellectual, Edward Said defines the intellectual as an in- 
dividual gifted with a special "faculty" to convey a certain message or vision to the public. He also pinpoints that "in the Arab Islamic world, the two words used for intellectual are "muthaqqaf" or "mufakkir", the first derived from "thaqāfa" or culture (hence, man of culture), the second from "fikr" or thought (hence, man of thought)". Similarly, Raymond Williams in Keywords: A Vocabulary of Culture and Society describes intellectuals as those who perform a "mental effort" that causes any ideological or cultural impact in their societies. Hence intellectuals, as men of culture and thought, mainly employ their intellect to produce a cultural or an ideological output, hoping to cause a change. Said believes that the writer/intellectual is "someone who ought to be listened to as a guide to the confusing present". Since intellectuals are expected to conceptualize their society through their cultural production; encountering injustice and oppression triggered by the authority has given the intellectuals a valid subject matter for their writings. Literature, then, as intellectual pursuit turns out to be a medium for presenting an "alternative narrative" other than the one presented by the officials. Influenced by consecutive postcolonial hegemonic regimes, as his "different" poetic trajectory suggests, 'Amal Dunqul has enacted the role of the public intellectual. This role, according to Edward Said, is "carefully weighing alternatives, picking the right one in order to cause the right change" (Elkholy, 2017; Said, 2012: p. 11, 20, 102; Williams, 2014: p. 169).

In his study, Judhūr al-rafọ fì dîwā 'aqwāl jadìda 'an harb al-basūs (2002), Jihād Al-' arjā argues that 'Amal Dunqul gave his life, poetry and tongue to his position of refusing to be a partner in social and political waste. His poetry does not participate in begging, flattery and kowtowing to political parties and elites; it supports human values and freedom. Dunqul believes that poetry should take the position of opposition and resistance, and challenge what exists because it speaks for the dream of a more beautiful future. In other words, it expresses what is being created in our hearts by rejecting the reality of humiliation in which we live.

With regard to the link between 'Amal Dunqul's poetry and heritage, Al-'arjā believes that his cultural heritage does not restrict the poet to the past. Rather, it bestows upon him the power to understand the present and its issues. It allows the poet to be busy with the concerns of his time and nation yet able to bring historical figures into his context. This prevents the poet from bragging about himself and his emotions and sings about all his achievements, but, alternatively, makes him concerned and worried about his nation and men in general. It also serves to help the poet intensify and deepen the meaning of his message, adding to it the credibility and sacredness of the heritage in the recipient's soul. This gives the modern poem the objectivity that is a defining feature of contemporary poetry (Al-'arjā, 2002: p. 1, 4).

3) Al-ḥidād Yalīqu bi Qạ̣r Al-nadā-Mourning Becomes Qaṭr Al-nadā

a) Historical background

The second poem we examine talks about the marriage of Princess Qatr 
Al-nadā, the daughter of Khamārawayhi, to the Abbasid Caliph Al-Mu'țadid. People still repeat this story today, combining what is historical and known as real with what is folklore created by people over the centuries. In terms of the characters in the poem, Khamārawayhi (250-282 AH) is Khamārawayhi Ibn 'Aḥmad Ibn Ṭūlūn, born in Sāmarrā', who was one of the kings of the Tulunian state of Egypt. He ruled in $270 \mathrm{AH}$ and established a garden and a palace, which was one of the most admired buildings of its time. He was brave and determined, and liked entertainment. He was killed by his sons. Qaṭr al-Nadā (287 $\mathrm{AH}$ ) is 'Asmä', his daughter, one of the most famous women in Arab history, known for her intelligence, beauty and literary compositions. She was married to the Abbasid Caliph Al-Mu'tadid and died in Baghdad and was buried in Al-Russāfa, Iraq (Hussayn, 2012: pp. 250-251).

b) The poem

Literature of resistance is considered by many Intellectuals a medium of struggle against any form of oppression not merely a tool for documentation of any historical moment. Resistance is defined by Selwyn R. Cudjoe in his book Resistance and Caribbean Literature as "any act or complex of acts designed to rid a people of its oppressors" (Cudjoe, 1980: p. 19). Literature becomes an essential tool used by writers to fight back their oppressors. In this way, "speaking truth to power" can be a manifestation of resistance according to Cudjoe's definition. Barbara Harlow asserts that the role of literature and writers during the struggle correlates with any forms of armed or political resistance. Resistance literature continues to wage a struggle for liberation on many levels and settings. This ongoing struggle is part of its political and cultural agenda. The role of literature has become fundamental in struggle movements, so poets have been regarded as the "guerilla fighters" of resistance movements. She maintains that the role of poetry in the liberation struggle itself has been a crucial one, both as a force for mobilizing a collective response to occupation and domination and as a repository for popular memory and consciousness (Harlow, 1987: pp. 33-34). Literature, as such, is used by many intellectuals and writers to voice the agony and oppression of their people. Therefore, Dunqul's poetry proves to be a true example of resistance literature (Elkholy, 2017).

The poem, Al-hidād Yalíqu bi Qatr Al-nadā, depicts the luxurious and wealthy life of Khamārawayhi who enjoyed all the comforts of life. He sought pleasure at the expense of the poor people; he was separated from the people, their worries and their problem. He used his position to justify his extravagance and decadence. His daughter, Qațr al-Nadā, was taken and held captive by the Abbasids. Her father was weak and could not free her from captivity. Because of this, Khamārawayhi was portrayed as a failed leader, far from a determined symbol of command and someone who lived by stealing people's money within a politically and morally corrupt regime. Such a life of extravagance led to the death of his conscience.

c) Employing the folk song in the poem

A very important and popular component of folk literature is folk tales. These 
include myths, legends, fairy tales, anecdotes, short stories, etc. In addition, proverbs, riddles, ballads, songs, rhymes, etymologies, folk titles, metaphors, chain letters, poetry, etc. are all part of the folk literature. Most of these elements which form part of folk literature have been created and passed on by word of mouth, some of them have been essentially oral literature now preserved in script and some have been traditionally preserved in written form (Kutty, 2002: p. 8).

The act of linking the past and the present is a prominent feature of modern Arabic poetry. The poet in the modern era tries to return to the past to establish a relationship with his heritage so that his identity is complete. The poet studies his heritage to understand the present and its issues and concerns (Al-'arjā, 2002: p. 4). Some researchers believe that the new cannot come without us looking at and surveying the old. The creative process does not occur without the author having looked at various resources, the most important of which is his national heritage. If the creative author desires to be closer to his readers, he has to discover and exploit his heritage, which enables him to interact and communicate with his audience. He also has to show the presence of this heritage in different manifestations in his poetry because many elements of the heritage interact with his creations, becoming intermediaries able to communicate with his readers. Spanning the bridges of dialogue using his cultural heritage means highlighting his own identity, communicating with the keepers of the cultural heritage inclination and those who care about preserving it and creating new connotations and diverse inspirations ('Abū Nidhāl, 1996: pp. 179-181; Jum 'a, 1983: pp. 84-86; 'Abd al-muțalib, 1995: p. 85).

In building his poem, 'Amal Dunqul exploits all the possibilities of expression at the level of the rhythm, image, symbols and exploits the techniques used by various arts such as theatre, cinema and plastic arts. The central motif of the poem lies in its divisions. The poem includes passages separated by punctuation marks, which are characterized by a semantic homogeneity, as well as the continued growth of the movement of the meaning from one section to another. Such a form resembles a story or a novel whose parts become increasingly complex, before it suggests a certain ending or before leaving the ending open to everyone's individual interpretation. Endowing the poem with theatrical forms makes both the poem's narrator and the choir actors within it. How do we know that Dunqul made the choir a part of the events described by the poem? The choir is the one that proclaims the news of the fall of Qațr Al-nadā into captivity (Hussayn, 2012: p.254).

In Representations of the Intellectuals, Edward Said (2012) states that the intellectual has always been associated with being isolated in an "ivory tower and a sneer". Conventionally, the intellectual was regarded as one who is constantly trying to recollect extra sophisticated individual pursuits to conceptualize everything into terminology. As a result, the word "intellectual" gained a bad reputation due to being connected to "arrogance and egotism", according to Helen 
Small. Said, on the other hand, views intellectuals as public figures who have a special faculty for passing knowledge to the society. Their performance has to transcend any "slogans, orthodox party line, or fixed dogma". Their own task must be going beyond stereotypes that thwart "human thought or communication". He also asserts that "real intellectuals are never more themselves than when, moved by metaphysical passion and disinterested principles of justice and truth, they denounce corruption, defend the weak, defy imperfect or oppressive authority". As such, intellectuals should discard any political, religious, or ideological affiliation. They shall also exert their ultimate effort, trying to point out oppression and violence caused by the authority. Being "the disturbers of the status quo", intellectuals shall be truthful and sincere enough to be able to antagonize the authority, disinterested in any material or class interests. In other words, they shall adopt skepticism instead of conformity as an ideological stance. They shall be non-conformists who cannot be easily co-opted by governments, or a functionary or employees who abide by the rules or governments or any similar institutions. In this way, real intellectuals, as seen by Said, are those who are in a constant conflict with the authority in order to reflect the suffering of the people (Said, 2012).

Amal Dunqul, using his heritage, especially his national and religious heritage, tries to shape his countrymen's national sensibilities (Nür al-dīn, 1984: p. 169). Dunqul co-opts the characters and elements, which are part of his heritage, and uses them to defend the rights, glory and development of his people. His poetry, thus, for 'Amal Dunqul, constitutes a "means of connecting". In his perspective, a poet such as he cannot break with his heritage; he must be aware of it and work toward its renewal (Jiḥ̄a, 1999: pp.243-244). 'Amal Dunqul says that

[T]he poet in the Arab world, under the social and political circumstances, is required to do two tasks: first, artistic through being a poet, second, national through being an worker who serves the national issues and progress, neither through political catchwords (slogans) nor through screaming and shouting but through revealing the heritage of the Arab nation, awakening its sense of belonging and deepening the bonds of unity among its countries (Fādilil, 1997: p. 358; author's translation from the original Arabic).

Dunqul, therefore, refused to belong to any political party or governmental organization to avoid being co-opted by the authority. He even developed as a strong opponent of the authority using his poetry as a tool to defy what he saw as atrocities of dictators. His main goal, as he himself stated it, was to advocate justice and freedom through his writings. His poetry exposes the increasing political corruption; and faces the hegemony practiced by the postcolonial regimes of Nāṣir and Sādāt (Elkholy, 2017; al-Riwīnī, 1983: p. 83).

In the folk songs of the Arab world, two interconnected words are used over and over again: Muhr (the horse) and the Khayyāl (the cavalier). These two words occur in many contexts and situations, most important of which are: heroism, chivalry, defense of the country, honor, and love stories. Examples of such 
folksongs are the following:

i) "When, you, my sweet, come to my mind,

The time of love comes to my mind,

O country, if a danger knocks on your door,

We will make you a fence with our hands and spirits.

They set the dowry of my beloved country,

It is a bride and its horse is our dear blood

And you cavalier, the one who rides your horse

Make the dowry occur on the sky".

ii) "I cry for my beloved and say, 'Oh, shame,'

And I scream from the bottom of my heart $\mathrm{O}$ shame, $\mathrm{O}$ shame,

The horse without a cavalier would bite its back,

The dream of being lost $\mathrm{O}$ shame, $\mathrm{O}$ shame,

The gold, my love, is still gold,

And the blame weighs the love,

Though he deserves it, what blaming is for".

iii) "Oh country, 'Um al- iqāl/No matter what happens to you/you return to your origin,

And the night with the eyes of hope is impossible/and above the foothills of the mountains is your name,

With $\mathrm{O}$ and roundelay/I love your painting with the dust of the dream,

That who loves the horse is the cavalier/in the path of loyalty and dream is your connection,

A girl with a shawl on her head/taking its beauty to your body with pride,

The dress is white and it is bleached with a necklace/who knew your dowry,

Your children are a fire with a waterfall on its top/it turns the seasons of the year with your semester,

And the lover of the hat is the one holding the iqāl/on the head of the old as your age,

And who loves the horse is the cavalier/he knows how to step on your plain"

(author's translation from the original Arabic).

Dunqul uses these two words taken from the folksongs and roundelays in his poem Al-hidād Yalīqu bi Qaṭ Al-nadā-Mourning Becomes Qatr Al-nadā (Būmālī, 2014; Dunqul, 1987). He, however, changes the context to express Egypt's political and moral corruption, and the loss of the real, determined political leadership that cares for the interests of the people. In Dunqul's view, Egypt is like the horse without a cavalier-it is a country without ethical standards and the organizational basics ruined by favoritism, bribery, extortion, the exploitation of power for private gain, stealing and losing the nation's money, the loss of social security, the absence of equality, the lack of government oversight, weak rule of law, and the absence of justice. The institutions of the state are undermined and weak. Corruption, fraud, deception and moral decay are the dominant values, while the values of magnanimity, heroism, equestrianism and legal standards have disappeared. 
The poet starts his poem with "yā līl yā 'īn", (O night $\mathrm{O}$ eye), which phrase is used in many Arab folksongs. Lubnā Al-Qunțār says the term "yā līl yā 'īn" spread because it is easy to pronounce and brings sweetness to both the mind and soul. Further, the term's concept symbolizes things more than its true meaning, as if its purpose is a fictional moral, because singing is a monologue to the world of dreams and association of thoughts. Singing "yā lìl" is a general emotional appeal with an improvisational melody taking into account the good use of Maqāmāt, melodies, direct singing, and the moving and exciting melodic transitions that drive away boredom and excite the listener, pushing him to ask for more. The scholar and music critic, Șamir Al-Sharif, states that the opening term of "yā lìl yā 'īn" is a kind of emotional singing that evokes feelings and sorrows. According to Maḥmūd 'Ajjān, the origin of singing "yā lìl yā 'īn", calling to the night and the eye, indicates a lack of sleep; he mentions that the phrase was used a lot in both old and new Arabic songs, either in the classical or colloquial languages. It is natural that those unable to sleep would call the night and feel sorry for the eyes that are deprived of sleep. Using the two words of night and eye also means calling the night and supporting staying up at night. Using "yā 'īn" followed by "lill" makes the two calls equal in terms of the musical terminology, i.e., what applies to the word "yā 'īn" applies to "yā līl” (Al-madīna news, 2016).

This opening in 'Amal Dunqul's poem comes to describe the poet's sad and suffering psyche. The poet's psyche is linked to his situation, which is linked to that of his family and his nation, which are in a tragic and sad situation. The poet wants to express his sadness and sorrow at the chaos and the political and moral corruption on the one hand, and the inaction and weakness of the presidents on the other. Governor Khamārawayhi, here in the poem, is the symbol of the contemporary Egyptian ruler who lives the life of extravagance with a government whose system is bound to collapse, having no hint of firmness. The ruler is surrounded by an elite that controls the nation's politics and economy to obtain wealth and money, ignoring the people's interests, rights and problems. Under the ruler's directions, the elite divides the country's resources and wastes money on luxuries, suppresses the people, increases their poverty, prevents their progress and development, and thwarts them from participating in and benefitting from the country's wealth. The spirit of the nation was weakened and people lost faith in the ruler because he could not save Qațr Al-nadā from captivity. The ruler remained in the framework of political catchwords (slogans) without actions, failing his national and moral duty and ignoring his citizens' concerns and suffering.

According to Jābir Kumịha, Qaṭr Al-nadā is a symbol of the stolen Egyptian and Arab land that was lost because of carelessness and neglect. As for Khamārawayhi, he is the symbol of extravagance and misuse of the land and the homeland, surrounded by singers and beautiful women. In this situation, no salvation was available for Qaț Al-nadā. At the end of the poem, both misuse of homeland and tragedy meet, and the tale is taken up by the voice and choir: 
"Khamārawayhi was sleeping lying on the mercury lake,

Who then would save this chained princess?

Who would save her?

Who would save her?

By sword,

Or by trick?"

(Dunqul, 1987: pp. 203-204; author's translation from the original Arabic).

Dunqul's poetry does not only document historical events, but also functions as a medium for social mobilization, urging people to resist oppression and dictatorship. Dunqul employed his poetry to serve the notions of freedom and justice instead of merely commenting on the historical events of his time. Intellectuals, such as Dunqul, are believed to play a vital role in reflecting the sociopolitical changes in their own societies by pointing out the corrupt administration of the authorities. They do not merely document the authorities' atrocities; they also spur the masses regardless of their own political affiliation to demand their rights. As an intellectual/poet, Dunqul regarded poetry as a way of reconstructing reality, a rejection of the status quo, a "perpetual revolution" with the aim of inciting people to ask for their rights (Elkholy, 2017).

Dunqul in his poetic career reimagined many historical and literary characters as personas to remind people of their glorious history and goad them to revolt against their oppressors. He believed that the Arabs were not going to gain their freedom and reform their societies except by reconsidering their history. His use of various historical figures as his mouthpiece was meant to provide his readers with a deeper insight into their past, allowing them, thus, the strength to change their future.

Amal Dunqul was called the "prince of protest poets". He was an Egyptian poet in permanent opposition to the figures of established authority, be it political, literary or religious. Dunqul's poems were original and unique contributions to modern Arabic poetry, especially with regards to his use of historical texts (Radwan, 2014) ${ }^{1}$. The poet explains that the extravagant and corrupt rulers of Egypt have made it a wasteland, making it a place for the greedy vying for control of it and its wealth. The government controls and despoils Egypt while its people suffer from the scourge of colonialism, similar to what Khamārawayhi the ruler did. He was eventually killed by his sons in his bed. He also lost Qațr Alnadā after he let her marry Abbasid Caliph Al-Mu'țadid (Kumịha, 1987: pp. ${ }^{1}$ Some of the most quoted verses in Egyptian revolutionary art come from the poem "Don't Reconcile" ("Lā tuṣālị̣") written by Amal Dunqul in November 1976 (Dunqul, 1987: pp. 324-336). Dunqul's poem expresses radical opposition to Sādāt's politics and the peace agreement with Israel. Almost three decades after his premature death, Dunqul, in Egypt known as the "prince of the refuser poets," has regained popularity in revolutionary circles and particularly in online activism. Some of his other poems were also rediscovered, quoted and rewritten in revolutionary cultural production. Sometimes, he was perceived as a prophet who predicted the January revolution, particularly with his poem “The Stone Cake” ("Ughniyyat al-ka'ka al-hajariyya”; Dunqul, 1987: pp. 274-280). The poem, written in the early 1970s, precisely described what would later occur in 2011 in the middle of Tahrīr Square, where "the voice erases the rest of the darkness/it sings for the newborn Egypt" (Botros, 2015). 
117-118). 'Islām 'Abū Ghafra believes that Qaṭr Al-nadā symbolizes Egypt, 'Amal Dunqul's home, which fought its enemy and then lost part of its land, as a result of Khamārawayhi's cowardice and weakness. Thus, the figure of Khamārawayhi became a symbol of every weak and frightened Arab who refused to stand by Egypt. This is shown clearly in the poem ('Abū Ghafra, 2018: pp. 119).

'Amal Dunqul introduces the choir technique into his texts by combining theatrical and poetic elements ('Abū Ghafra, 2018: p. 29). 'Aḥmad Al-dūsarī believes that the poem is characterized by equal shares (half-and-half style) of these elements. In other words, it has two symbols that move either in the direction of the other intersecting each other, or moving in parallel. The poem begins with the choir presenting Qațr Al-nadā, who in turn presents it as an explosion. The choir represents the nation in whose conscience Qațr Al-nadā constitutes a symbol of having been defeated:

"Choir:

Qațr Al-nadā, oh my uncle,

A horse without a cavalier,

Qațr Al-nadā, oh my eye.

Princess with two faces.

[......]

Choir:

Qaṭr Al-nadā, oh night,

Falls under horses,

Qațr Al-nadā, oh Egypt.

Qațr Al-nadā is in captivity.

Crossing Sinai,

passing through Bedouin tents, and in the depletion of water,

In the middle of the summer,

Dreaming of reaching Jordan,

Loosening the horses' reins around its water,

Washing the face of grief,

Qațr Al-nadā, oh Egypt,

Qaṭr Al-nadā is in captivity.

Qaṭr Al-nadā, Qațr Al-nadā”

(Dunqul, 1987: p. 201; author's translation from the original Arabic).

Then comes the single sound representing the totalitarian government and the control of the ruler; it talks about Khamārawayhi, who is lying on the mercury lake. The sound intersects with the choir to explode the dramatic conflict in the poem. The sound continues with the choir until the last passage when they meet: the voice and the choir (Al-dūsarī, 2004: p. 385).

\section{Conclusion}

The folk song is an anonymous, lyrical song, whose origins lie somewhere in the past, but which is still sung today. It represents the poetry of groups (ethnic, so- 
cial, national, etc.) and their music, whose customs are transmitted orally without the need for writing or printing. The folk song is associated with man's everyday social activities, and it touches large segments of people with different aspirations and orientations. The folksong expresses the concerns and sorrows of human beings, their ambitions, hopes and joys. Hence, we understand that the folk song is the product of man's psychological need, with all its broad range of emotions.

In many places, folk songs are of great importance, serving as incitements to war or love, or as a part of religious or secular rituals. Through them, the group expresses its common emotions or lightens the burden of communal labor. In certain preliterate groups and sometimes elsewhere, folk songs were used for magic effects, to defeat enemies, to attract lovers, to invoke the favor of supernatural powers. Sometimes the magic effect of these songs is so greatly valued that actual ownership of songs is maintained and their use carefully guarded. They may come to the owner in a dream or as the result of fasting or other ascetism.

Even when folk songs are not used for such practical purposes but only for the pleasure of singing or listening, the greater part of the world uses them for the expression of ideas or emotions held in common by the group (Thompson, 2017).

Folk songs are instrumental in people's mobilization for social movements. In the cultural and social context, folk art forms play a crucial role in raising social consciousness and shaping people's sensibilities towards various social movements. In many societies, their folk songs helped create and afterwards maintain a sense of identity and also spread and sustained the collective identity and consciousness among the people. The folk song, which has metamorphosed into protest and revolutionary songs, has been the mouthpiece protesting against all major social exclusion and inclusion indicators such as feudalism, social and economic exploitation, denial of power, resources exploitation, water crises, underdevelopment, drought, poverty, alienation, suppression of cultural identity, social injustice, bonded labor, migration of labor, suicides, gender inequality and caste discrimination (Krishnaiah, 2018; Morrison, 2003).

The Egyptian poet 'Amal Dunqul employs the traditions of Arabic folksongs to express his unfamiliarity with city life and its negative psychological, social and political impact. He also employs folksongs to criticize the prevailing political, social and economic conditions, and to increase peoples' sense of being part of one nation.

The poet includes folksongs in his poems, but changes the context to express the political and moral corruption in today's Egypt and the loss of an effectual political leadership that can care for the interests of the people.

\section{Conflicts of Interest}

The authors declare no conflicts of interest regarding the publication of this paper. 


\section{References}

'Abdu al-ḥāfiz, 'I. (2013). Dirāsāt fì al-'adab al-sha 'bì. Cairo: al-Hay'a al- 'āmma liquṣūr al-thaqāfa.

'Abdu al-lațif, M. (1964). 'Iwān min al-fan al-sha bì. Cairo: Dār al- ilm.

'Abd al-muțalib, M. (1995). Qirā’a 'uslūbiyya fī al-shi' r al-ḥadīth. Cairo: Dār al-m 'ārif.

'Abdullāh, Y. (2018). al-' adab al-sha 'bī wal-'ușțūra. 'ūd al-nid. https://www.oudnad.net/spip.php?article1063\&lang=ar

'Abū Ghafra, I. (2018). Al-sard fí Shi' r' Amal Dunqul. Gazza: Jāmi 'at al-' azhar.

'Abū Ghālī, M. (1995). Al-madīna fí al-shi' r al-'arabī al-mu' āṣir. Kuwait: 'Alam a-ma rifa.

'Abū Nidhāl, N. (1996). 'Alāmāt 'alā Tarīq al-riwāya fì al-'urdun. 'Ammān: Dār 'Zmina.

'Aḥmad, M. (2006). Turāth -al-mūsīqā al-sha biyya al-falasținniyya. Majallat Jāmi t al-najāh, 23, 106-108.

Al-'antīl, F. (1978). Bayna al-folklūr wal-thaqāf al-sha 'biyya. Cairo: al-Hay'a al-Mișriyya al-'Āmma li-l-Kitāb.

Al-'arjā, J. (2002). Judhūr al-raf̣̣ fí dīwān 'aqwāl jadìda 'an harb al-basūs. Gazza: al-jāmi a al-'islāmiyya.

Al-barghūthī, 'A. (1979). Al-' aghānī al-'arabiyya al-sha biyya fì falastīn wal-'urdun. Bīr Zeit: Mațba' at al-sharq al- 'arabiyya.

Al-dūsarī, 'A. (2004). 'Amal Dunqul: Shā'ir 'alā khuṭutụ al-nār. Beirut: al-Mu'assasa al-' arabiyya li-dirāsāt wa-nashr.

Al-gharfï, Ḥ. (2003). Al-nashīd al-' abadī: 'Amal Dunqul. Cairo: al-Majlis al-' a 'ā lil-Thaqāfa.

Al-jawharī, M. (2002). al-'bdā' wal-turāth al-sha 'bī. Cairo: Markiz al-buhūth.

Al-khafïfī, B. (2000). Al-ramz fì shi' $r$ 'Amal Dunqul. Libya: Jāmi à qār.

Al-madīna News. (2016). Mā howa 'aṣl kalimat "yā lìl yā 'īn" fì ' aghānīnā? Retrieved from http://www.jbcnews.net/mobile/article/187962-

Al-mikhlif, Ḥ. (2000). Tawḍ̂if al-turāth fì al-masrah. Damascus: Dār al-' awā'il.

Al-qalamāwī, S. (1966). 'If Layla walayla. Cairo: Maṭba 'at al-kutub al-Mișriyya.

al-Riwīnī, 'A. (1983). Al-janūbī. Cairo: Madbūlī.

'Ațiyya, 'A. (2016). Fī al-thaqāfa al-sha' biyya. Tripoli: Gross press.

Bauman, R. (1992). Folklore. In Richard Bauman (Ed.), Folklore, culture performances, and popular entertainments (pp. 29-40). Oxford: Oxford University Press.

Bidīr, Ḥ. (1986). 'Athar al-' dab al-sha 'bì fì al-' dab al-ḥadīth. Alexandria: Dār al-wafā.

Bin al-shaykh, A. (2007). Dawr al-shi' r al- 'arabī al-jazāirì fì al-thawra. Algeria: Wazārat al-thaqāfa.

Bin 'Āmir, S. (2006). Ṭayyārit waraq. Cairo: Dār Ṭība li-nashr.

Botros, A. (2015). Rewriting Resistance: The Revival of Poetry of Dissent in Egypt after January 2011 (Surūr, Najm and Dunqul), In F. Pannewick and G. Khalil (Eds.), Commitment and beyond: Reflections on/of the Political in Arabic Literature since the $1940 s$ (45-62). Reichert Verlag Wiesbaden: LR.

Būmālī, Ḥ. (2014). Al-ta addud al-lughawì fì al-qaṣìda al-' arabiyya al-mu'āṣira. Al-manhal. https://platform.almanhal.com/Files/2/64127

Cudjoe, S. R. (1980). Resistance and Caribbean Literature. Ohio: Ohio University Press.

Dhihnī, M. (1972). al-'dab al-sha 'bī al- 'arabī. Al-karṭūm: Maṭbū āt jāmi 'at al-qāhira.

Dunqul, 'A. (1987). Al-a 'māl al-shi riyya al-kāmila. Cairo: Maktabat madbūlī. 
Elkholy, O. (2017). The Egyptian Spartacus: The Poetry of Amal Dunqul. Majallat al-bahth al- ilmi, 18, 581-612.

Fāḍil, J. (1997). Qậāyāal-shi' r al-ḥadīth. Beirut: Dār al-shurūq.

Harlow, B. (1987). Resistance Literature. New York: Methuen.

Herder, J. G. (2013). Stimmen der Völker in Liedern. Hamburg: Verlag.

Herzog, G. (1950). Songs: Folk Song and the Music of Folk Song. In Maria Leach (Ed.), Standard Dictionary of Folklore, Vol. 2 (pp. 1932-1050). New York: Funk and Wagnalls.

Hūlkitinzār, 'I. (1982). Qāmūs mușṭalhăt al-'ithnolūgiā wal-folklūr. Miṣr: Dār al-ma ārif.

Ḥussayn, Sh. (2012). Dirāsat muwāzana bayna qașīdat wafīqa libadr shākir al-sayyāb wabayna qaṣīdat Al-ḥidād Yalīq bi Qaṭr Al-nadā li 'Amal Dunqul. Majallat Kulliyyat al-'dāb, 1(101), 246-264.

'Ibrāhīm, N. (1981). 'AShkāl al-Ta bìr fì al-' dab al-sha' bì. Cairo: Dār Gharīb.

'Iskandar, Y. (2005). Ta' wīliyyat al-shi' r al-'arabī. Baghdād: Jāmi' at Baghdād.

'Ismā' îl, B. (2015). Tamathulāt al' ughniya al-sha biyya. Algeria: Jāmi 't 'Abī bakr bilqāyid.

Jihā, M. (1999). al-shi' r al- 'arabī al-Hadīth. Beirut: Dār al- 'awda.

Jum 'a, Ḥ. (1983). Qậāāà al-'bdāe al-fannī. Beirut: Dār al-' dāb.

Khaḍāwī, 'U. (2015). al-' dab al-sha'bī: al-māhiyya wal-mawdhū' . Majallat al-thaqāfa al-sha'biyya, 30, 76-79.

Khūrī, J. (2004). Al-mașādir al-'adabiyya al-sha biyya lil-shi' $r$ al-'arabī al-Hadìth. (Doctoral Dissertation). Tel Aviv: University of Tel Aviv.

Khūrī, J. (2013). Al-folklūr awl-ghinā' al-sha'bī al-falasținnī. Haifa: majma' al-lugha al-'arabiyya.

Khurshid, F. (1994). Al-siyar al-sha 'biyya al-'arabiyya. Cairo: al-Hay'a al-Mișriyya al-'Āmma lil-Kitāb.

Krappe, 'A. (1967). 'Iim al-folklūr. Cairo: Wazārat al-thaqāfa al-Mișriyya, Dār al-kitāb.

Krishnaiah, K. (2018). The Role of Folk Songs in Social Movements: A Case Study on the Separate Telangana State Formation in India. European Journal of Multidisciplinary Studies, 3, 124-133.

Kumịhạ, J. (1987). Al-turāth al-'insānī fì shi' r 'Amal Dunqul. Cairo: Hajar li-ṭibā 'w wal-nashr wal-tawzī' wal-' i'lān.

Kutty, V. G. (2002). National Experiences with the Protection of Expressions of Folklore/ Traditional Cultural Expressions: India, Indonesia and the Philippines. Geneva, Switzerland: World Intellectual Property Organization (WIPO).

Macmillan Dictionary (2019). Folk Song.

https://www.macmillandictionary.com/dictionary/british/folk-song

Masā di, N. (2000). Al-binā’ al-fannī fì riwāyāt mu' nis al-razzāz. 'Ammān: Dār al-karmil.

Morrison, C. (2003). Not about Nationalism: The Role of Folk Song in Identity Process. Paper Presented at the Student Conference, 3, Columbia University, New York. http://www.fulbright.hu/book1/cecilymorrison.pdf.

Muḥammad, B. S. (1998). al-'adab al-sha 'bì. Algeria: Dīwān al-mațbū 'āt al-sharqiyya.

Mursī, 'A. (1970). Al-'ughniya al-sha 'biyya. Cairo: al-Hay'a al-Mișriyya al- 'Āmma li-l-Kitāb.

Mursī, 'A. (1987). al-'adab al-sha 'bī: al-muștalaḥ wa-ḥudūduhu. Majallat al-funūn al-sha 'biyya, 21, 14-26.

Națūr, 'A. (2008). Al-'ughniya al-sha 'biyya fì al-jazā'ir. (Doctoral Dissertation). Algeria: Jāmi't mintūrī. 
Naẓī, W. (1967). Al-'ādāt al-miṣriyya bayna al-'ams wal-yawm. Cairo: Dār al-kātib al-'arabī li-Ṭibā' a wa-Nashr.

Nūr al-dīn, Ș. (1984). Hudūd al-naṣ al-'adabī. al-Dār al-Baydhā' : Dār al-Thaqāfa.

Radwan, N. (2014). Amal Dunqul, The Prince of Protest Poets. Journal of Arabic Literature, 45, 218-243.

Said, E. (2012). Representations of the Intellectual: The Reith lectures. New York: Vintage Books.

Șāliḥ, 'A. (1971). Al-' adab al-sha 'bì. Cairo: Maktabat al-nahdha al-'arabiyya.

Shams al-dīn, M. (2008). Al-'ughniya al-sha biyya bayna al-dirāsāt al-sharqiyya wal-ghar biyya. Cairo: al-Hay'a al- 'āmma liqușūr al-thaqāfa.

Ṭālibī, J. (2017). Dirāsat al-ru' ya al-jadīda fī tajribat 'Amal Dunqul. Majallat al-lugha al- 'arabiyya wa' ādābuha, 13, 81-89.

Taymūr, M. (1960). Dirāsāt fì al-qiṣṣa wal-masrah. Al-jamāmīz: al-maṭba a al-namūdhijiyya.

Thompson, S. (2017). Folk Literature. Encyclopedia Britannica. https://www.britannica.com/art/folk-literature.

Williams, R. (2015). Keywords: A Vocabulary of Culture and Society. New York, Oxford: Oxford University Press.

Wordnik. (2019). Folk Song. https://www.wordnik.com/words/folk\%20song

Zakkūr, M. (2016). Tawzîf al-turāth al-sha bì fì namādhij min riwāyat bin hadūqa. bin hadūqa. http://www.benhedouga.com/ 